\title{
Teatro da Paz: histórias invisíveis em Belém do Grão-Pará?
}

\author{
Roseane Silveira de Souza ${ }^{2}$
}

RESUMO: Um dos principais exemplares de arquitetura neoclássica no Brasil, o Teatro da Paz, em Belém do Pará, tem sua imagem e história bastante marcadas por uma ampla remodelação, realizada entre 1904 e 1905, quando ganhou as feições luxuosas que mantém até hoje. Essa reforma teve como efeito o ofuscamento de fatos havidos entre a construção (1 869-1 874), os nove primeiros anos de funcionamento (1878-1887), e sua primeira reforma (1887-1890), envolvendo maus tratos de negócios públicos, disputas de poder entre engenheiros provinciais, litígios, apropriações públicas do teatro-monumento, e a participação dos artistas Domenico de Angelis e Chrispim do Amaral nas obras de reforma. Desvelar essas histórias invisíveis, à margem da história oficial, restitui ao monumento sua dimensão humana, social.

PalavRAS-ChaVE: Teatro da Paz. Belém. Grão-Pará. Patrimônio Histórico. História Social.

ABSTRACT: Teatro da Paz ("Peace Theater"), in Belém, capital of State of Pará, is one of the most representative neo-classical opera houses in Brazil. Its remarkable history and features resulted of a deep process of architectonic renewal occurred between 1904 and 1905, when it had also a sort of rich elements of decoration incorporated. As a result, the process hidden facts happened from the building (1869-1878), following by the opening and functioning (1878-1887), until the first important renovation (1887-1890), involving improper management of public sources, conflicts between engineers, litigations, the intense public uses for nine years and the participation of two recognized artists, the Italian Domenico de Angelis and the Brazilian Chrispim do Amaral, in the first renovation. Uncovering these invisible histories, outsider histories, give to monument back its human, social dimension.

KEYWORDS: Teatro da Paz. Belém. Province of Pará. Cultural Heritage. Social History.

No romance Chove nos Campos de Cachoeira (1941), do escritor paraense Dalcídio Jurandir ${ }^{3}$, o menino Alfredo sonha em partir da pequena Cachoeira do Arari, na ilha do Marajó, para ir estudar na capital do Pará. Alfredo cria uma Belém particular, na medida do seu desejo, e, para isso, muito contribuem
1. Artigo dedicado ao pesquisador Vicente Salles, ao jornalista Lúcio Flávio Pinto e às fotógrafas Paula Sampaio e Maria Christina.

2. Jornalista e historiadora, doutoranda em História na Pontifícia Universidade Católica de São Paulo. E-mail: silveirissima@gmail.com

3. Dalcídio Jurandir Ramos Pereira (Ponta de Pedras, PA, 10.1.1909 - Rio de Janeiro, RJ, 16.6.1979). O romance citado integra o conjunto literário batizado, pelos especialistas, de Ciclo do Extremo Norte, que recebeu, em 1972, o prêmio Machado de Assis da Academia Brasileira de Letras; ver Dalcídio Juran$\operatorname{dir}(1997)$. 
4. Idem, p. 99-100.

5. As reflexões que orientam $o$ artigo partem da dissertação de mestrado da autora, sob a orientação da professora Estefânia Knotz Canguçu Fraga, tendo a pesquisadora recebido bolsa da Capes e do CNPq; ver Roseane Souza (2009). as histórias contadas pela vizinha Rosália, que todos os meses ia à capital receber seu montepio. Ela havia trabalhado no Teatro da Paz, seu orgulho: "Eu, eu vesti muita artista. Cada roupagem! Era ver uma princesa. Fui camareira do Teatro da Paz!", dizia, para a desconfiança de todos. "Camareira do Teatro da Paz! pasmava Cachoeira. Os conterrâneos de Rosália achavam demasiado, até mesmo irritante, que ela chegasse a ser camareira do maior teatro do norte do Brasil!"4

A ficção dimensiona o real significado do Teatro da Paz para os nortistas. Construído entre 1869 e 1874, mas inaugurado apenas em 1878, em decorrência de um litígio entre o governo e o arrematante das obras, a edificação é, no país, um dos exemplares de teatro-monumento em estilo neoclássico. Mais especificamente, um teatro de ópera. É uma das arquiteturas de grande volumetria construídas na capital do Pará, como ostentação da riqueza proveniente da economia de exportação do látex a partir da segunda metade do século XIX, período de intensa atividade no setor de obras públicas - o "termômetro invariável do progresso dos povos", segundo as palavras de Ambrósio Leitão da Cunha, um dos 60 presidentes nomeados pelo imperador D. Pedro II para a Província do Pará, entre os anos de 1852 e 1889.

A monumentalidade e seu significado para a cultura e a sociedade na Região Norte inscreveram, no Teatro da Paz, uma história bela, homogênea e ideal, sobretudo no marco temporal da belle époque amazônica, entre as décadas de 1890 e 1910, quando a própria cidade passou por uma remodelação. No curso dessas transformações, uma reforma realizada no teatro, entre os anos de 1904 e 1905 (na gestão de Augusto Montenegro, governador do estado, e do intendente municipal Antônio Lemos, personalidades emblemáticas da Belém da belle époque), deu a ele as feições luxuosas que ostenta até hoje (Figuras 1, 2, 3 e 4). Essa foi, na sua história, a segunda obra de vulto e a mais drástica quanto ao resultado.

Este artigo tem por objetivo narrar três episódios, ocorridos entre os anos de 1869 e 1890, que foram obscurecidos por essa reforma, refletindo-se, a partir deles, sobre o esquecimento, na história, e o sentido de público, na administração provincial do Pará ${ }^{\text {. }}$ O primeiro episódio versa sobre a construção fraudulenta, de 1869 a 1874, que acabou na seara da justiça; o segundo, sobre as intensas apropriações públicas durante os nove primeiros anos de funcionamento (1878 a 1887), a partir do que se falava sobre ele na imprensa, incidindo sobre as sociabilidades no interior do teatro. Por fim, o terceiro episódio aborda a reforma ocorrida entre 1887 e 1890, quando, entre outras providências para sanear pendências do processo construtivo, foram inseridas as decorações internas do edifício, com destaque às pinturas da sala de espetáculos: a Alegoria da República, do pernambucano Chrispim do Amaral; e a alegoria do plafond, de autoria do italiano Domenico de Angelis. Nesse ponto, são discutidos, de modo geral, os embates entre os artistas e o governo provincial quanto à condução de seus contratos de trabalho; e, em particular, problemas sobre a temática e a técnica da pintura de De Angelis, e a autoria do pano de boca de Chrispim do Amaral. 


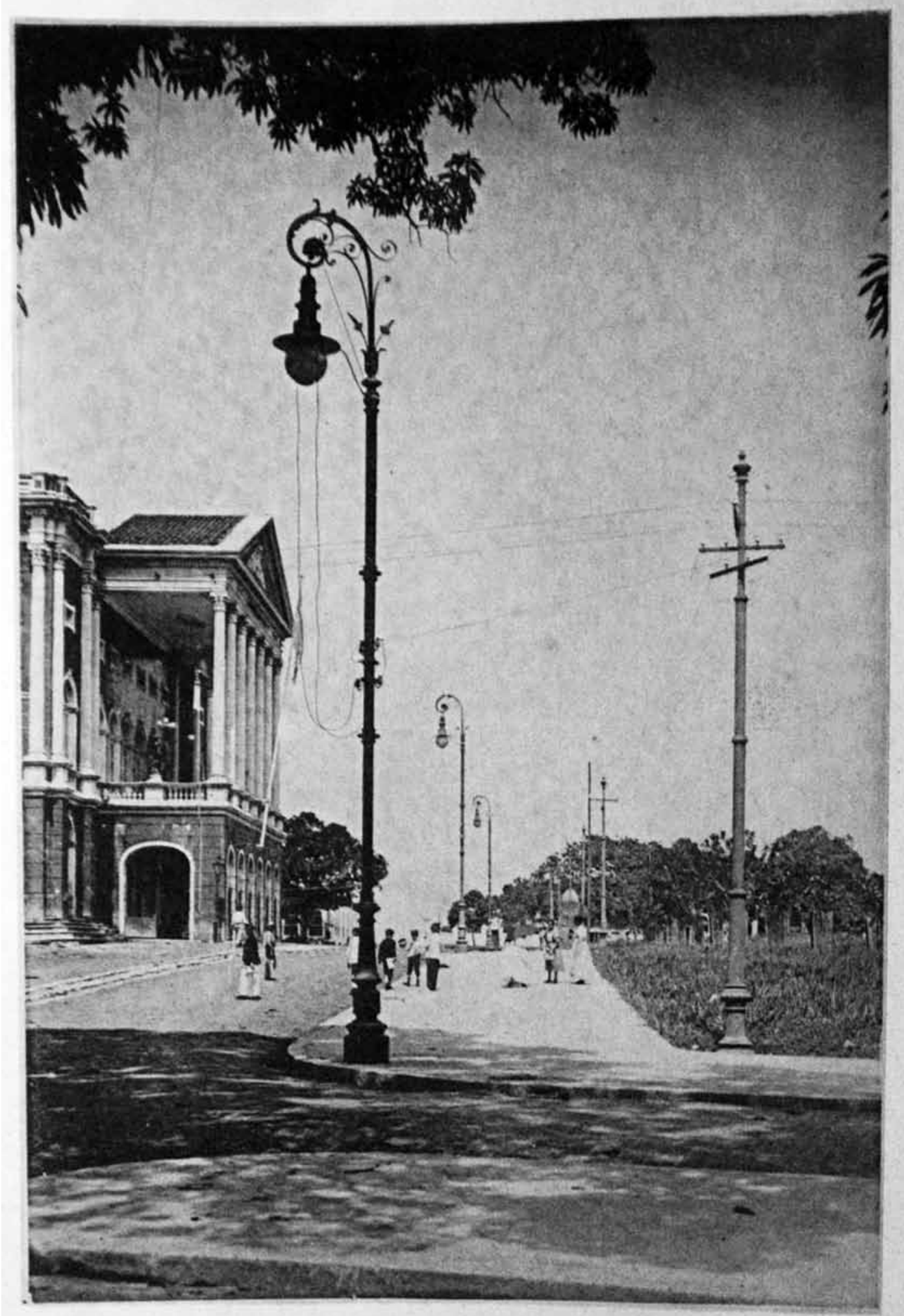



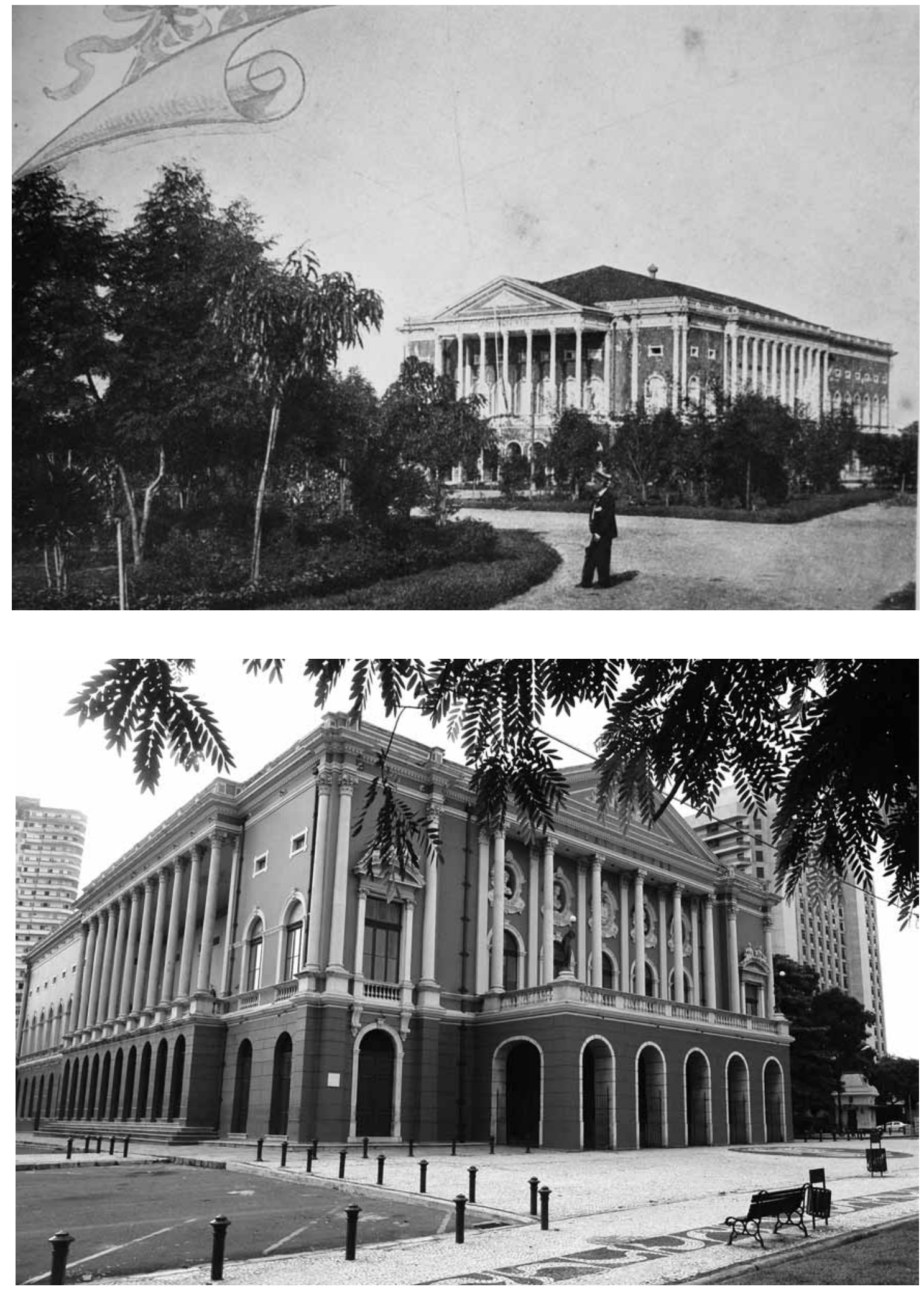


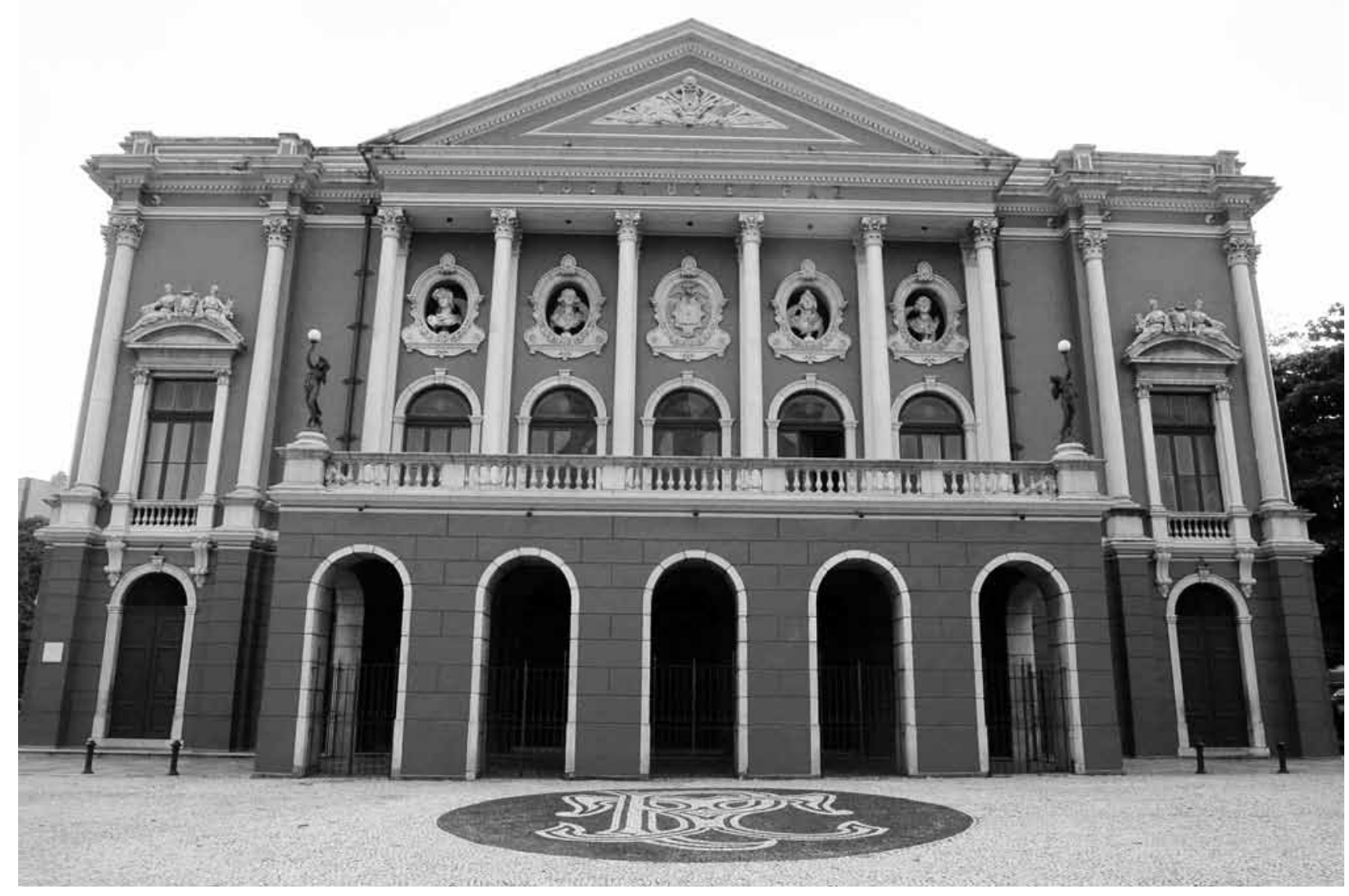

Figuras 1, 2, 3 e 4 - $\bigcirc$ Teatro da Paz, em Belém do Pará, sofreu transformações em sua fachada: as sete colunas originais (aqui em fotografias de 1898) foram corrigidas e substituídas por uma colunata par, em 1904. Fotografias e reproduções cedidas pela fotógrafa. (C) Paula Sampaio.

As fontes dessas histórias estão: na documentação da Secretaria da Presidência da Província e nos Ofícios da Administração do Theatro da Paz, pertencentes ao Arquivo Público do Estado do Paráb; em notícias de jornais paraenses do século XIX7; em relatórios de governo ${ }^{8}$, pertencentes ao acervo da Biblioteca Pública Estadual Arthur Vianna; no acervo do Museu da Universidade Federal do Pará/Sala Vicente Salles9; e na documentação provincial digitalizada do Center for Research Libraries (CRL), fundo Brazilian Government Document Digitalization Project ${ }^{10}$. As principais referências bibliográficas provêm da obra do historiador paraense Vicente Salles ${ }^{11}$, sobretudo a dedicada ao teatro e à música do Pará.

mote das reflexões baseia-se no porquê e no como das invisibilidades. Invisibilidade, aqui, situa-se no campo epistemológico relacionado à memória e ao esquecimento, observando-se, aí, duas operações: uma, política; outra, historiográfica. A primeira diz respeito às dinâmicas governamentais republicanas de apagamento do passado representado pelas heranças imagéticas do regime monárquico, o que é observado na remodelação urbana de Belém a partir da década de 1890. Nesse projeto está incluída a reforma em edificações dos séculos XVIII e XIX, entre elas a do Teatro da Paz. A segunda consiste na
6. Ver Fontes: arquivos $\mathrm{e}$ acervos.

7. Ver Fontes: periódicos Além de outras não diretamente citadas aqui, como edições diversas de: $A$ Constituição, em 1878; Diário de Notícias, em 1882, 1883 , 1890; O Liberal do Pará, em 1873, 1875, 1878, $1883 \mathrm{e}$ 1889.

8. Ver Ernesto Mattoso (1907); Governo do Estado do Pará (1899; 1908).

9. Ver Intendência Municipal de Belém (1902); e A Exposição (1895).

10. Ver Fontes: Arquivos e acervos; e Almanak Laemmert (1883).

11. Ver Vicente Salles (1960; 1968; 1994; 2001a; 2001b; 2007). 
12. Cf. Antonio Mitre (2002, p. 26-27).

13. Em 1912, acusado de ser mentor de um suposto atentado ao senador Lauro Sodré, seu arqui-inimigo, Lemos teve incendiada a sede de seu jornal A Província do Pará por pessoas insatisfeitas com a situação. Sua casa foi invadida e saqueada, e ele teve de sair de pijama, às pressas, pelas ruas da cidade até ser acolhido pelo próprio Sodré. Em seguida, partiu para o Rio de Janeiro, onde morreu em 2 de outubro de 1913. reinterpretação das fontes, e não apenas em seu acúmulo, objetivando outra historiografia, a partir do esquecimento da história instituída, como prescreve Antonio Mitre: "O ponto de partida [de uma ciência do esquecimento] poderia ser a constatação de que o conhecimento historiográfico, exegético em essência, é sobretudo uma renovação do sentido"12. Mitre propõe um esquecimento "com método", sem fetichização das fontes, para o fortalecimento da dimensão conceitual do trabalho do historiador.

Do ponto de vista metodológico, houve a releitura de uma documentação administrativa (já conhecida) em torno da construção do teatro; e a apuração de outra, que se encontrava inédita los ofícios administrativos do período entre 1880 e 1900), cruzando, ambas, com informações obtidas em jornais e na obra de Vicente Salles. O resultado do confronto dessas fontes com a historiografia já instituída apontou os vazios, as invisibilidades de uma parte significativa da história do teatro, que precisavam ser trazidas à luz, inclusive para desfazer equívocos - como o da autoria do pano de boca, sempre atribuída ao cenógrafo francês Eugène Carpezat.

Esclarecendo um pouco mais sobre a reforma de 1904-1905, a justificativa para sua realização foi o aparecimento, em 1902, de uma rachadura no frontão. Por causa disso, a fachada foi redesenhada, com a demolição de um alpendre, que the impunha certo desequilíbrio visual, e o recuo do frontão e de uma colunata. Desse modo abriu-se um terraço, onde hoje os frequentadores podem ser avistados nos dias de eventos. A antiga colunata, curiosamente projetada em número ímpar (sete), contrariando a paridade das regras clássicas da arquitetura, foi ajustada para ter seis colunas. Mas o projeto foi além: o palco e a sala de espetáculos foram remodelados, mantendo-se, no entanto, o desenho da sala - em forma de ferradura (Figura 5) e em vários planos, conforme o modelo italiano, a exemplo do Scala de Milão. Vários elementos decorativos foram introduzidos, tanto interna quanto externamente, e o sistema de iluminação elétrica foi aperfeiçoado.

Ele passara, finalmente, a ter a imagem de sua função: ser um teatro de ópera, dentro de um sistema visual de opulência e beleza, como convinha à arquitetura da grande ópera. $\bigcirc$ fetiche das narrativas da Siá Rosália - e o monumento divisado por tantos outros cidadãos reais, transeuntes da praça da República, onde ele se ergue - era este Teatro da Paz: um teatro para ser contemplado sob a perspectiva republicana da cultura de imagens.

O projeto político subjacente à reforma do teatro era claro: reassentar a pedra de originalidade na arquitetura do monumento. Uma tentativa bem sucedida, pois é essa imagem do teatro que catalisa a memória envolvendo a edificação, obscurecendo fatos havidos desde sua construção até o final da primeira reforma, entre 1889 e 1890, coincidindo com o advento da República. Assim, histórias de fraudes, disputas e conflitos foram apaziguadas pela construção imagética de um teatro ideal, belo e ordenado, que, além de metáfora da cidade, tornou-se também um marco de saudade, com o fim da Era da Borracha, em 1912 - expresso, simbolicamente, pela expulsão humilhante de Antônio Lemos ${ }^{13}$, após renunciar ao cargo -, e o início da decadência econômica da capital. É 


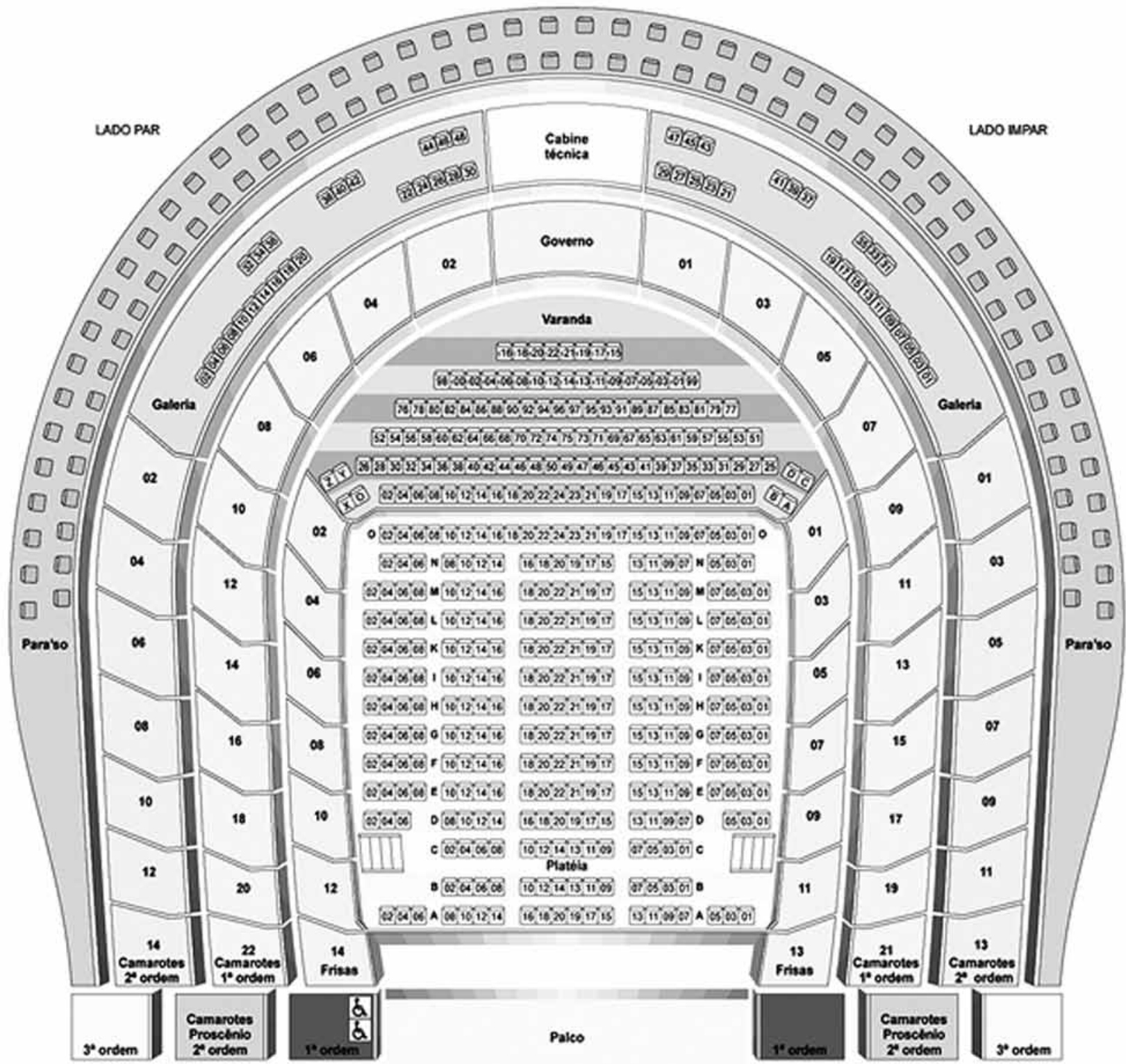

国

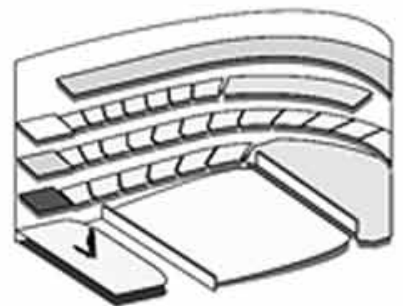

Figura 5 - Mapa da sala de espetáculos do Teatro da Paz, na qual se observa a forma de ferradura e os vários níveis da plateia. Imagem de livre acesso, obtida na página oficial do teatro. 
ainda esse teatro a baliza para as inúmeras obras nele empreendidas ao longo do século XX até a mais recente, entre os anos de 2000 e 2002.

Construir e civilizar

Na Amazônia do século XIX, edificar era dominar a natureza, abrir as portas da região ao progresso, à civilidade, à higienização e à ordenação das cidades, significando o combate aos costumes considerados atrasados da população. Por este prisma, construir teatros, museus, bibliotecas, escolas, para citar alguns prédios públicos, era um projeto político de modernidade. Na região, esse projeto começara no século XVIII, quando Belém teve seu poder político e econômico ampliado sob os auspícios da Coroa Portuguesa, no plano estratégico de assegurar o domínio da parte setentrional de seu território no Novo Mundo - lembrando que, até 1823, o então Estado do Grão-Pará e Rio Negro era administrado diretamente pela Coroa, não integrando o Estado do Brasil, condição adquirida apenas com a Adesão do Pará à Independência, em 15 de agosto de 1823.

No Pará, o Teatro da Paz foi a primeira casa de espetáculos erguida com recursos públicos, depois de inúmeras tentativas, desde a década de 1820, de edificação de um teatro provincial. Na verdade, entre 1780 e 1812, funcionou a Casa de Ópera, ou Teatro Cômico, projetada pelo arquiteto bolonhês José Antônio Landi, a serviço de Portugal, na lateral do Palácio do Governo. Sobre ela, pouco se sabe além das informações de cronistas da época e de plantas da cidade onde aparece localizada. Entrou em ruína.

Para suprir a ausência de um teatro oficial, a administração da Província arcava com o arrendamento de teatrinhos particulares, como o Providência, improvisado em um casarão no largo das Mercês. Para o deleite da plateia, empresários recebiam subvenções do governo e promoviam temporadas de companhias nacionais e portuguesas. Esse panorama sucinto mostra a importância da atividade artística no Grão-Pará, uma tradição surgida com o teatro jesuítico do século XVII. Paulatinamente, entre os séculos XVIII e XIX, o gênero lírico, os dramas e as comédias passaram à preferência do público, sinalizando a introdução de costumes europeus na região.

A decisão de construir um teatro tomou forma no processo de expansão da cidade para o interior do território. A partir de um projeto de urbanização iniciado em 1848, com a intensificação do dessecamento de pântanos e seu consequente aterramento, além do arruamento do sítio e de outros nos arredores, a área conhecida como Campina tornou-se o novo centro da cidade. Na década de 1860, já batizada de praça Dom Pedro II, essa área se transformou num espaço de diversões, congregando hotéis, bares, cafés, circos, prostíbulos e teatros de rendez-vous. Um terreno fértil, portanto, para a construção de um teatro provincial, selando o destino, dessa praça, de ser um espaço de convergência dos símbolos da modernidade em Belém. 
Em 1863, a Assembleia Provincial aprovou, e Francisco Carlos de Araújo Brusque, presidente da Província, sancionou a lei autorizando a construção do teatro, ao custo de 150 contos de réis. Apenas em 1868, na administração de José Bento da Cunha Figueiredo, foi autorizada a despesa para a obra, ampliada para 400 contos de réis. Em 3 de março de 1869, realizou-se a cerimônia de assentamento da pedra fundamental do Theatro de Nossa Senhora da Paz, uma alusão à expectativa de encerramento da Guerra do Paraguai (1864-1870). Mas logo seria adotado oficialmente o nome mais curto: Theatro da Paz.

A construção

Do ponto de vista de maus tratos em negócios públicos no Brasil, especialmente em obras públicas, o processo de construção desse teatro é exemplar: disputas pelo poder entre engenheiros, falta de planejamento e de fiscalização, malversação do dinheiro público e outras mazelas compuseram as desventuras humanas na criação desse monumento que deveria conduzir a capital do Grão-Pará aos ideais de progresso e civilidade.

Na verdade, tal modus operandis predominou na maioria das obras empreendidas na capital do Pará, quando a exportação da borracha passou a ter impacto na balança comercial do Império, a partir da década de 1850. 0 setor de Obras Públicas, criado naquela mesma década, reunia engenheiros sob o comando de um diretor, que devia satisfações diretamente ao presidente da Província. Eram funcionários de grande prestígio, representantes de tradicionais famílias ricas do Pará, e influentes politicamente, não sendo raro encontrá-los nos altos cargos, incluindo o de presidente. $\bigcirc$ setor também esteve vulnerável à alternância dos partidos Conservador e Liberal no poder, chegando, inclusive, em dezembro 1871, quando o conservador Abel Graça foi nomeado presidente, ao fechamento da repartição. Ele extinguiu o setor, desmantelando o grupo de engenheiros, e impôs novas regras à condução das obras públicas. Era, alegadamente, uma forma de enxugar a máquina administrativa, resultando na exoneração, do cargo de diretor, de um liberal de peso: o matemático e empresário José Coelho da Gama e Abreu, futuro Barão de Marajó. O setor só foi recriado em 1881.

Do começo ao fim, a obra do Teatro da Paz esteve suscetível a toda essa sorte de instabilidades. Intrigas entre os engenheiros, por exemplo, foram sentidas desde a apresentação do projeto original, solicitado, em dezembro de 1868, pelo presidente Cunha e Figueiredo ao então diretor da Repartição das Obras Públicas, Gama e Abreu. O encarregado do serviço foi o engenheiro Antônio Augusto Calandrini de Chermont, que teria seis meses para apresentar o plano. Mas este surpreendeu-se, dois meses depois, quando o presidente aprovou o projeto do engenheiro-militar pernambucano José Tibúrcio Pereira de Magalhães, contrariando todos os membros da repartição. Eles julgavam Magalhães 
14. Ver Ata (1869); grifado no original. incompetente para executar o serviço, pois desconheceria as regras da arquitetura cênica.

Magalhães apresentou um projeto semelhante, pelo menos na fachada, ao do Teatro Bordeaux, na França, onde se destaca a colunata do frontispício, o elemento arquitetônico de maior agrado do autor do projeto original do teatro paraense. Mas não demorou muito para os membros da repartição encontrarem 12 infrações às regras de arquitetura e pedirem explicações ao engenheiro. No dia 8 de março de 1869, em uma reunião constrangedora convocada pelo conselho da diretoria da repartição, Magalhães foi sabatinado quanto às propostas apresentadas, sendo confrontado com expressões duras e ferinas, como constam da ata do encontro. Por exemplo, o conselho considerou inominável o modo pelo qual ele pretendia estruturar a colunata, a parte principal de seu projeto, perfurando o fuste das colunas, fazendo passar uma barra de ferro por entre elas.

É uma construcção de que os membros da Directoria não tem conhecimento em um só edificio, entre tantos que se achão reproduzidos em tão numerosas obras publicadas sobre estes assumptos. Accresce ainda que um entrecolumnio em que as columnas teem mais de cincoenta e quatro palmos de altura, isto é, tanto quanto a altura total do Palacio do Governo; seria uma monstruosidade num theatro de segunda ordem, alem de recahir no caso em que é aconselhado pelos mestres de architectura, serem empregadas ordens sobrepostas, ou arcadas com columnatas sobre ellas ${ }^{14}$.

Nem tanto ao mar, nem tanto à terra. As alterações apontadas pelo conselho foram aprovadas pelo presidente, à exceção da colunata, mantida conforme o desenho de seu autor. No entanto, Magalhães não permaneceu em Belém para acompanhar a obra, retornando a Recife, sua cidade natal, para comandar as obras de reconstrução do Teatro Santa Isabel, incendiado em 1869. Por ironia, Calandrini de Chermont foi encarregado de fazer as alterações na planta e, claro, tratou de mudar totalmente o desenho da fachada, propondo um hall de entrada formado por arcos e sobre ele uma espécie de alpendre constituído por uma colunata encimada por um frontão. Além disso, fez acréscimos substanciais em obras de cantaria, encarecendo a construção; e, reduzindo os recursos para outras partes da obra, promoveu aberturas laterais na edificação, entre outros detalhes.

Estranhamente, e comprovando a má gestão das obras públicas, apesar de o plano de Calandrini de Chermont ter sido aprovado apenas em novembro de 1869, a obra fora iniciada em junho desse ano, tendo por base a planta de José Tibúrcio Pereira de Magalhães (!), orçada em 465 contos de réis. $\bigcirc$ orçamento do novo projeto só ficou pronto em abril de 1870, elevado a mais de 582 contos de réis. Com isso, o contrato com o arrematante, o empresário português João Francisco Fernandes, foi assinado em 1869 e, a partir de 1870, aditado várias vezes, por conta das alterações propostas não só no novo projeto mas também em ajustes provenientes de decisões posteriores, completamente fora de controle. Vieram daí tanto a sucessão de problemas no cumprimento do contrato quanto a falta de parâmetros para a fiscalização do andamento da obra 
até sua entrega definitiva, em 1878, a apenas dois dias da inauguração do prédio, ao custo aproximado de 800 contos de réis.

De 1872 a 1875, o governo provincial nomeou várias comissões para avaliar o processo de construção, a fim de autorizar, ou não, o pagamento do arrematante e, ao final, receber definitivamente o edifício. Em 1872, um grupo de engenheiros constatou haver uma discrepância entre o orçamento e a obra, a necessidade de acréscimos para melhorar a segurança e a beleza do edifício, e a obrigatoriedade de o arrematante ressarcir o tesouro público por ter construído a menos do que informara. No ano seguinte, a imprensa denunciava a falsificação das plantas arquitetônicas do teatro, acusando Calandrini de Chermont. A essa altura, ele não era mais responsável pela fiscalização da obra e, mesmo se defendendo publicamente sobre a denúncia de falsificação, ficou com a imagem arranhada nesse episódio.

A cada nova necessidade de medição das obras, havia a dificuldade em formar comissões. Nenhum engenheiro queria assumir a responsabilidade, e alguns alegavam suspeição, por terem feito negócios imobiliários com o empreiteiro do Teatro da Paz. Sob o peso da pressão da presidência da Província, as comissões eram formadas, apontando o evidente: o teatro que se construía não era o mesmo desenhado na planta. A comissão de 1874, por exemplo, constatou sérios problemas estruturais, a começar pela profundidade e espessura das paredes, diferentes em cada parte do prédio; o uso de madeiramento fraco onde deveria haver alvenaria ou ferro; a fragilidade e o defeito da estrutura do telhado; a desproporção da colunata da fachada; o número de camarins menor do que o projetado; a decoração deficiente; o emprego de material de má qualidade, entre muitas outras observações. Resultado: obra condenada. E o trabalho da comissão foi considerado suspeito, por ter suscitado muitas desavenças entre os engenheiros envolvidos.

A comissão de 1875, formada por engenheiros convidados pelo governo, foi ainda mais rigorosa, atacando o relatório de suas antecessoras. $\bigcirc$ grupo, medindo cada metro quadrado da obra e verificando detalhes da estrutura, constatou haver fraude na sua condução a partir de erros crassos na execução e na fiscalização, beneficiando financeiramente o arrematante. Chegara "ao jogo indecente da ganância", conforme o relatório, publicado oficialmente no jornal O Liberal do Pará, em 3 de julho de 1875.

No extenso relatório dessa comissão, é interessante verificar a concepção de monumento, relacionando-o aos seus aspectos memorial e material. Na explanação sobre a espessura das paredes, sob o entendimento de que elas são a parte mais importante de todo edifício, a solidez torna-se um atributo da monumentalidade e da permanência no tempo. $\bigcirc$ Teatro da Paz seria, assim, um monumento contraditório com suas paredes finas, irregulares e pouco duráveis.

Resistencia a toda prova, tal é o caracter fundamental dos monumentos. E assim n'ol-o attestão os que ainda hoje dão conhecimento das eras primitivas e de todos os tempos passados.

Portanto as paredes do monumento devem ter uma resistencia maxima.

Quando o edificio não deva apresentar o caracter monumental, sendo apenas destinado a satisfazer uma necessidade de época, não é preciso dar ás paredes a resistencia maxima,

Annals of Museu Paulista. v. 18. n.2. July.-Dec. 2010. 
15. Cf. Theatro de N. S. da Paz (1875b).

16. Idem, $1875 \mathrm{a}$ mas tão sómente aquela que the transmitta a força e duração propria de todas as couzas pertencentes ao Estado ou para o serviço do Estado.

O theatro de N. S. da Paz, que não é destinado a satisfazer uma necessidade passageira, mas permanente, levando ás gerações futuras o conhecimento do estado actual, deveria apresentar o caracter fundamental dos monumentos, isto é, paredes espessas e de maxima resistencia.

Entretanto a comissão examinou e vio que a espessura das paredes d'este theatro está abaixo da resistencia minima, e d'ahi concluio que [...] é um edificio construido para durar um tempo relativamente pequeno ${ }^{15}$.

Os resultados do trabalho dessa comissão foram a condenação do arrematante a pagar multa no valor de 40 contos, por ter excedido o prazo de entrega do edifício, e a devolver dinheiro aos cofres públicos, por obras não feitas. A comissão de 1872 foi punida com a exoneração de seus membros, à exceção do engenheiro fiscal Julião Honorato Corrêa de Miranda, que faleceu durante a polêmica. Entre os ex-diretores e os ex-engenheiros fiscais da repartição, todos mais ou menos responsáveis pelos erros, nenhum foi punido, nem Calandrini de Chermont.

Mesmo assim, com essas decisões do presidente conservador Francisco Maria Corrêa de Sá e Benevides, até os editorialistas de O Liberal do Pará, jornal do Partido Liberal, surpreenderam-se, publicando uma nota com o seguinte teor:

Accumulam-se escandalos sobre escandalos; abre-se mercado para todos os negocios administrativos, e a impunidade, acoroçoando a pratica d'estes actos, tem levado a provincia ao maior gráo de descredito que se pode imaginar.

No paiz e no estrangeiro a provincia do Pará passa actualmente pela mais corrompida do imperio, e o desfaçamento dos empregados prevaricadores tem attrahido sobre o funccionalismo o desconceito e o desprezo geral ${ }^{16}$.

$\bigcirc$ processo construtivo virou processo judicial, pois o arrematante recusou-se a cumprir a determinação presidencial de concluir as obras. $\bigcirc$ problema se estendeu por mais três anos, tempo em que o teatro permaneceu fechado, à mercê de invasões e das ações meteorológicas. Em 1877, uma avaliação, a última, demandada pelo governo ao engenheiro Martinho Domiense Pinto Braga, reiterava a série de problemas já conhecidos e descritos no relatório anterior. Segundo ele, com o passar do tempo, só pela circulação de uns poucos curiosos pelo prédio, as escadarias já estavam desalinhadas. Naquele mesmo ano, foi estabelecido um acordo entre o governo e o arrematante, que prosseguiu as obras. $\bigcirc$ governo tratou logo de contratar a companhia artística do empresário Vicente Pontes de Oliveira e, no dia 13 de fevereiro de 1878, - Teatro da Paz foi recebido oficialmente pelo presidente da província João Capistrano Bandeira de Mello Filho, que o inaugurou, com pompa e circunstância, no dia 15. 
A inauguração do Teatro da Paz foi um dos acontecimentos mais concorridos de 1878, competindo com as eleições de novos deputados provinciais para o Parlamento Nacional. Liberais e conservadores embatiam-se novamente no campo da política partidária, estendida aos domínios da imprensa. Mas nem mesmo os jornais dos partidos deixaram de atiçar a curiosidade do público paraense com pílulas noticiosas sobre os preparativos da inauguração do teatro. Eram informações sobre a companhia artística, a inauguração do sistema de iluminação, a venda dos ingressos, entre outras novidades.

A noite da abertura levou ao teatro a "gente escolhida" de Belém, como os jornais costumavam referir-se à classe alta. Ao redor do edifício, populares se acotovelavam para ver a movimentação dos carros e a chegada dos convidados. Um espetáculo à parte. $\bigcirc$ presidente da Província foi saudado com foguetes e por uma banda de música. Aberta a cena, ouviram-se o Hino Nacional e a marcha Gram-Pará, de autoria do maestro maranhense Libânio Colás. Em seguida, Colás regeu a ópera As Duas Órfãs, de A. D'Ennery, com os artistas da Empresa Vicente. Com sua companhia, Vicente Pontes de Oliveira levou à cena nomes conhecidos do público da capital: Manuela Lucci, que também era sua esposa, Emília Câmara, Joaquim Infante da Câmara, Júlio Xavier de Oliveira, Xisto Bahia e Maria Bahia. A temporada contou, ainda, com Guilherme da Silveira, João Máximo Coelho e Chrispim do Amaral, cenógrafo e ator. Posteriormente, o elenco foi ampliado com a contratação de Rosa Manhonça, Izabel Maria Cândida, Cândida de Mendonça, Augusto Cezar, A. C. Braga, Martin C. Manhonça e Carlos David.

Belém viu, "afinal", abrirem-se as "goelas" do monstro, como registrou o ácido jornalista José Veríssimo sobre a noite da inauguração.

Até que afinal! Não ha mal que sempre dure nem bem que nunca se acabe. Este pensamento popular é de inteira applicação aqui. A primeira parte diz respeito ao publico, ao thezouro provincial, ao arrematante da obra, etc.; a segunda aos honrados senhores que tem tido a fortuna de serem engenheiros fiscaes e... e muita gente mais.

Foi ante-hontem, ante-hontem 15 de fevereiro deste bem aventurado anno de 1878, que aquelle monstro abriu as goéllas a todos nós que queríamos ver o que se passava nas suas entranhas.

Era o dia marcado para a abertura da assembléa provincial. Erão dous theatros que se deviam abrir. Lucraram todos e muito principalmente os que pagam impostos ${ }^{17}$.

Veríssimo escreveu críticas semanais em $\bigcirc$ Liberal do Pará a respeito de 47 espetáculos encenados ao longo daquele ano - no total, 126 récitas, incluindo pequenas cenas. $\bigcirc$ conjunto de sua Chronica Theatral é um importante documento sobre a crítica às artes cênicas no Pará, enfocando a dramaturgia e seus autores, a performance dos artistas, a qualidade dos cenários e figurinos. São textos marcados, sobretudo, pela defesa do escritor, incentivando a adoção da estética realista na cena paraense, reverberando um movimento iniciado na 
18. Idem, 1878b. Veríssimo escreveu esta crônica por ocasião da apresentação de Os Enjeitados, do dramaturgo português António Ennes. A peça é um protesto contra as rodas dos enjeitados, onde eram colocados os recém-nascidos indesejados, garantindo-se o anonimato de quem praticava o ato. A peça estreou em Lisboa em 1876 e chegou ao Brasil no mesmo ano, sendo aqui largamente representada. No Pará foi apresentada apenas em 1878. No Rio de Janeiro ficou em cartaz nos anos de $1876,1878,1880$ e 1881.

19. Ver José Veríssimo (1878c). O ator referido por Veríssimo é o português António Soares de Medeiros, intérprete do papel-título e renomado artista no Brasil e em sua terra natal.
Europa e liderado, no Brasil, por José de Alencar e Machado de Assis. A reforma realista do teatro brasileiro tinha por base uma proposta pedagógica de transformação do gosto estético do público. Em Belém, como na Corte, o grande público deliciava-se com os dramalhões, os melodramas e as comédias, repetindo o velho repertório dos teatrinhos particulares das cidades. Veríssimo mostrava-se implacável com o público, culpando-o pela qualidade das peças levadas à cena no Teatro da Paz.

O realismo é uma escola essencialmente critica, póde por isso não ser definitiva, mas o que para nós é incontestavel, é que esse modo de ser da arte, é filho legitimo do nosso estado de civilisação, das conquistas do nosso estado de civilisação, das conquistas do nosso progresso, na ordem intellectual. A velha litteratura, hoje gasta, é incapaz de uma missão social; isolada no seu subjectivismo, é simplesmente uma arte egoista e hypocrita, vivendo fóra do mundo, odiando-o e, as vezes, bajulando-o ${ }^{18}[\ldots]$

Diante de um drama phantastico, onde as apparições sobrenaturaes, offendendo o bom senso, misturam-se á realidade da vida, a critica, ainda a mais benevola, sente-se impotente para condemnar, ou antes para julgar. Por isso, sorri de despreso e lastima apenas que um artista de talento, como no caso presente, seja quem assigna o drama que ouvimos na quinzena finda e que se chama $O$ bom anjo da meia-noite.

$\bigcirc$ theatro, onde n'este momento se devem agitar as graves questões sociaes, perde immenso com isso; e o culpado não é nem um actor mediocre; é um artista quase celebre.

máo gosto do nosso publico, devemos confessar, é tambem connivente n'esse attentado. É elle quem preferindo as composições apparatosas e burlescas, ás obras sérias e de merito, anima os autores a escreverem-n'as e aos actores a represental-as ${ }^{19}$.

Até 1880, os espetáculos por ele criticados subiram à cena do Teatro da Paz com exclusividade. Naquele mesmo ano, depois de romper unilateralmente o contrato com Vicente Pontes de Oliveira, o governo trouxe a primeira temporada de ópera com a Companhia Lírica Italiana, dirigida pelo empresário Tomas Passini. A estreia ocorreu em 7 de agosto, com a ópera Ernani, de Giuseppe Verdi. Em cena, Filomena Savio, soprano dramático, a grande estrela da companhia. A partir daquela temporada, outras se sucederiam, alternando-se com apresentações dramáticas, estações carnavalescas, números circenses e eventos políticos. Em 1882, a temporada lírica teve como convidado de honra o compositor e maestro Carlos Gomes, no auge da fama. Diante do sucesso da temporada, ele retornou ao Pará em 1883, empresariando uma companhia, mas o empreendimento foi um fiasco. Os preços altos dos ingressos e a epidemia de varíola, que matou vários artistas e técnicos da companhia, esvaziaram as sessões.

Portão afora, antes e depois de sua inauguração, o Teatro da Paz impactou profundamente a dinâmica da praça Dom Pedro II. Sua construção motivou a melhoria daquele sítio urbano, ampliou a oferta de transporte público (bondes), e inflacionou o mercado imobiliário. Morar perto do teatro era um privilégio; vender imóveis no entorno da edificação, a certeza de bom negócio. Mesmo fechado, à época do litígio de seu processo construtivo, ele instigava a curiosidade da população. 
Aparentemente sem segurança, serviu de morada para um mendigo, abriu-se à visitação de curiosos e era alvo de pedradas dos transeuntes, chegando a ter suas calhas entupidas. Foi, assim, incorporando-se à rotina da cidade, sendo apropriado pela população de diversas formas - diversas táticas, como Michel de Certeau denomina os modos pelos quais os consumidores, os cidadãos comuns interpretam e reinterpretam os produtos dos sistemas estabelecidos nas estratégias das instituições, ao ordenar sociopoliticamente o espaço urbano ${ }^{20}$.

Nessa perspectiva, o monumento foi sendo tomado não apenas no uso de sua função cênica, mas como um artefato sobre o qual recaíam desejos, memórias, disputas e poderes. $\bigcirc$ teatro estava na boca do povo, nas páginas dos jornais, na publicidade, nas prateleiras das lojas que vendiam roupas e acessórios apropriados para a estação lírica; nos restaurantes, que ofereciam cardápio especial durante as temporadas artísticas; nos bares e cafés que recebiam os artistas. As agências onde eram vendidos os ingressos enfeitavam-se a cada nova temporada. Sem falar na oferta de trabalho para costureiras, sapateiros, camareiras, gráficos e outros operários. $\bigcirc$ que nele se passava era assunto na cidade, e a cidade era repassada dentro dele, no encontro do público a cada novo espetáculo.

Na imprensa, especialmente, as recorrências ao Teatro da Paz davam-se não apenas nos noticiários, mas nas cartas dos leitores, nos pedidos dos espectadores aos dirigentes das companhias, na crítica feita aos artistas e em crônicas ambientadas no "lírico". No Diário de Notícias, por exemplo, havia uma seção intitulada Vida Moderna, em que o cronista Diplomata mantinha um diálogo com uma certa Senhora para criticar, em tom pejorativo, os hábitos dos frequentadores do teatro. Além disso, os artistas dirigiam seus agradecimentos ao público, aos apoiadores e aos que thes ofertavam presentes. Enfim, era um do teatro do público. Mas de qual público?

Convencionou-se associar o Teatro da Paz às classes mais abastadas da província do Pará. Barões da borracha, banqueiros, comerciantes, pecuaristas, profissionais liberais, famílias tradicionais, enfim, seriam o seu público potencial e definitivo. Havia, claro, uma intenção evidente no projeto do governo de edificar um teatro público voltado à "classe mais illustrada da população", como registrou o presidente Henrique Beaurepaire Rohan, em relatório de 15 de agosto de 1856. Mas não foi só isso o que ocorreu.

Na documentação administrativa, no noticiário e na bibliografia consultada, há muitas evidências referindo-se à participação de outros segmentos sociais na audiência do teatro. Havia, pois, um desejo coletivo de consumo dos valores subjacentes às artes encerradas naquele teatro. Ou seja, o desejo pela cultura burguesa não se restringia, de uma forma previamente determinada, a uma classe social. Além disso, a realização de espetáculos subvencionados ou desonerados da taxa de locação, propiciando a redução no preço dos ingressos, pode ser uma explicação válida para a presença de estudantes, operários e outros trabalhadores nas sessões. As famílias ricas também levavam consigo parentes e aderentes de outras classes sociais, e mesmo os seus escravos. 
Na década de 1840, era vedado o acesso de escravos aos teatros. O regulamento do Teatro Providência era claro quanto a esse aspecto. Mas, depois de 1871, com a promulgação da Lei do Ventre Livre, a entrada dos cativos estava liberada. Há indícios de sua presença no último pavimento, enquanto aguardavam seus senhores; e eles foram alvo também de sessões artísticas, promovidas em favor de sua liberdade, comparecendo para receber a carta de alforria.

Essa convivência implicava tanto a tolerância quanto a animosidade. Havia uma guerra de linguagens na vivência da sala de espetáculos do Teatro da Paz, motivada pela própria divisão do espaço, à maneira dos teatros do século XVII - notadamente o teatro italiano, cuja plateia tem forma de ferradura dividida em pavimentos. Camarotes de primeira, segunda, terceira e quarta ordem, plateia e paraíso, a conformação original da sala de espetáculos, segmentavam o público conforme o bolso e a moral.

As famílias ricas, por exemplo, deveriam ocupar os primeiros e segundos camarotes - um sinal de status, pois ficavam no nível do camarote do presidente da Província, hoje do governador do Estado. As moças e senhoras deveriam sentar-se ao fundo dos camarotes, resguardando-se dos olhares, embora - cronista Diplomata reclamasse de moças debruçadas nos balaústres. As mulheres, de um modo geral, não deveriam ocupar a plateia, para não ficarem mal faladas. A plateia, o local mais devassado pelos olhares, o gesto destruidor das fronteiras físicas, era reservada para os homens. A quarta ordem e o paraíso, dispostos no último pavimento, eram os lugares mais baratos, conformando quem só podia pagar esse ingresso e quem queria um pouco mais do que assistir aos espetáculos.

No último pavimento ficavam, por exemplo, os assuadeiros, os espectadores barulhentos e bagunceiros, sempre dispostos a provocar os ocupantes dos outros pavimentos. Na década de 1880, a polícia recebia, pela imprensa, muitas manifestações de pessoas inconformadas com os espectadores que, antes dos espetáculos, cantarolavam um lundum, de autoria do artista Xisto Bahia, intitulado Camaleão, cuja letra ironiza a elite política e suas mutações oportunistas. Essa música fazia enorme sucesso nos cortiços, daí ser associada às classes baixas. No teatro, as cantorias poderiam ser acompanhadas de assobios ou pela percussão do bater de pés e de guarda-chuvas no chão.

Camaleão

Eu conheço muita gente

Igual a um camaleão

Com a cabeça diz que sim

Com o rabinho diz que não.

Segura, meu bem, agarra, amarra o camaleão. (bis) 
As virtudes deste bicho

São de grande estimação

Ele é filho do patronato

É sobrinho da eleição.

Segura, meu bem, agarra, etc.

Se ele é verde ou amarelo

Responda algum sabichão

Tem as cores do estadista

Que pra si serve a Nação.

Segura, meu bem, agarra, etc. ${ }^{21}$

Entre os assuadeiros havia os pateadores: do verbo patear, bater o pé no chão em sinal de reprovação. Em teatro, patear um artista, uma apresentação, era um gesto considerado muito agressivo. Mas era prática, nos teatros brasileiros, como parte das torcidas em torno das companhias e, particularmente, dos artistas. Aliás, brigas entre torcidas foram comuns mesmo nos teatros parisienses no século XIX. Os espectadores iam aos tapas por esta ou aquela estrela, e a briga podia ganhar a rua. Essas animosidades reeditaram-se no Pará. Já no antigo Teatro Providência, havia pateadores que atiravam feijões no rosto dos artistas, caso reprovassem sua performance. $O$ pesquisador Vicente Salles relata um episódio ocorrido na década de 1840, quando militares de alta e baixa patente foram repreendidos pela polícia por organizarem pateadas ${ }^{22}$.

Pelas fontes pesquisadas, os ataques dos pateadores, no Teatro da Paz, eram combinados na surdina, mas a notícia a respeito podia vazar na imprensa, deixando a polícia em alerta. Nas noites de espetáculos, as companhias já ficavam sobressaltadas pela possibilidade de uma manifestação agressiva, podendo, ou não, concretizar-se a ameaça.

Na temporada de 1882, uma cena foi flagrante dessa prática. A Companhia Lírica Italiana de Tomas Passini, empresariada pelo maestro paraense José Cândido da Gama Malcher, estreou, em 23 de agosto, a ópera Norma, de Vicenzo Bellini, tendo como estrelas o soprano Libia Drog e o tenor Ferdinando Ambrosi. No meio do espetáculo, ele, que apresentava sinais de cansaço por causa da extensa turnê, foi substituído pelo segundo tenor, Alessandro Puggi, cuja performance foi detestada pela quarta ordem, formada, nesse dia, por estudantes. Deu-se início a uma barulheira, e o diretor da companhia foi pressionado a comparecer à cena para ser pateado. A manifestação foi duramente reprimida pela polícia, que retirou com violência os estudantes de dentro do teatro. Nos dias seguintes, a imprensa comentava o caso, de forma parcial, apoiando ou reprovando a ação da polícia, tecendo acusações para todos os lados. Uma guerra de palavras. $\bigcirc$ episódio repercutiu mal na cidade, e a temporada chegou a ser esvaziada.

Por conta dessas ocorrências já conhecidas, mas não exclusivamente por causa delas, o controle das posturas dentro do Teatro da Paz tomou forma
21. Esta música foi gravada em 1902 pela Odeon, sendo um dos primeiros registros fonográficos feitos no Brasil. A cantora brasileira Maria Martha fez uma gravação recente; ver Xisto Bahia (1902).

22. Cf. Vicente Salles (1994, p. 20) 
em regulamento aprovado no ano de 1883. Na verdade, o documento fora elaborado em 1878, pelo Conservatório Dramático Paraense, criado em 1873, com vários objetivos, entre eles o de elaborar o regulamento do Teatro da Paz. Sintonizado com a política de controle das condutas e da moralidade adotada pelo Império, na qual o papel da polícia era antes a ordenação da cidade do que a repressão, o regulamento estabelecia a Polícia do Teatro, subordinada à Chefia de Polícia da Província. As atribuições do grupamento iam desde o controle da venda dos ingressos à vigilância dos gestos - os dos artistas em cena e os do público.

Essa regulamentação não mascarava, no entanto, as regalias concedidas pela administração do teatro às famílias, como o tratamento era generalizado. Desde o processo construtivo até as primeiras temporadas, havia interesse da administração em diferenciar a entrada de cada segmento do público, para não misturar os grupos da quarta ordem com as famílias. Por exemplo, em 1886, o administrador João Olympio Rangel encaminhou um ofício à presidência da Província solicitando melhorias na casa de espetáculos, entre elas a colocação

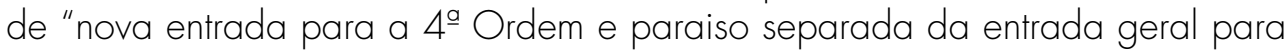
evitar que as famílias se vejão obrigadas a envolver-se com a classe de gente que frequenta aquella Ordem"23.

Nas relações sociais em Belém, os códigos de assepsia presentes, se inseriam a cidade, por um lado, no "espírito" do século XIX de controle do corpo do cidadão e do espaço urbano, por outro reforçavam a herança colonial de negação e repressão dos costumes locais, principalmente aqueles associados às classes populares, os "iletrados", os "selvagens". Mas "aquela classe de gente", "aqueles indivíduos", "aquelas gentes dos paraísos" pagavam para entrar. E, na lógica do mercado, quem paga, leva. Então, o jeito era conviver com eles.

Dentro do teatro, apenas um movimento era capaz de encerrar essa guerra: o apagar das luzes no início de cada espetáculo. Era o verdadeiro sentido de todos estarem ali.

\section{A primeira reforma}

De 1887 a 1890, o Teatro da Paz esteve fechado para a primeira grande reforma de sua história - período pouco referido nos levantamentos históricos realizados sobre a edificação, possivelmente pelo fato de a documentação correspondente ter ficado inacessivel até 1997, quando foi identificada e organizada no Arquivo Público do Estado do Pará. Se há um aspecto mais ofuscado da história do teatro depois da reforma de 1904-1905 é justamente essa obra, quando foram inseridas as pinturas artísticas da sala de espetáculos: o pano de boca de cena intitulado Alegoria da República (Figura 6), de Chrispim do Amaral, e o plafond (teto) e as pinturas decorativas das dependências da plateia (Figura 7), de autoria do italiano Domenico de Angelis. Em determinadas referências, as pinturas são dadas como pertencentes à obra 


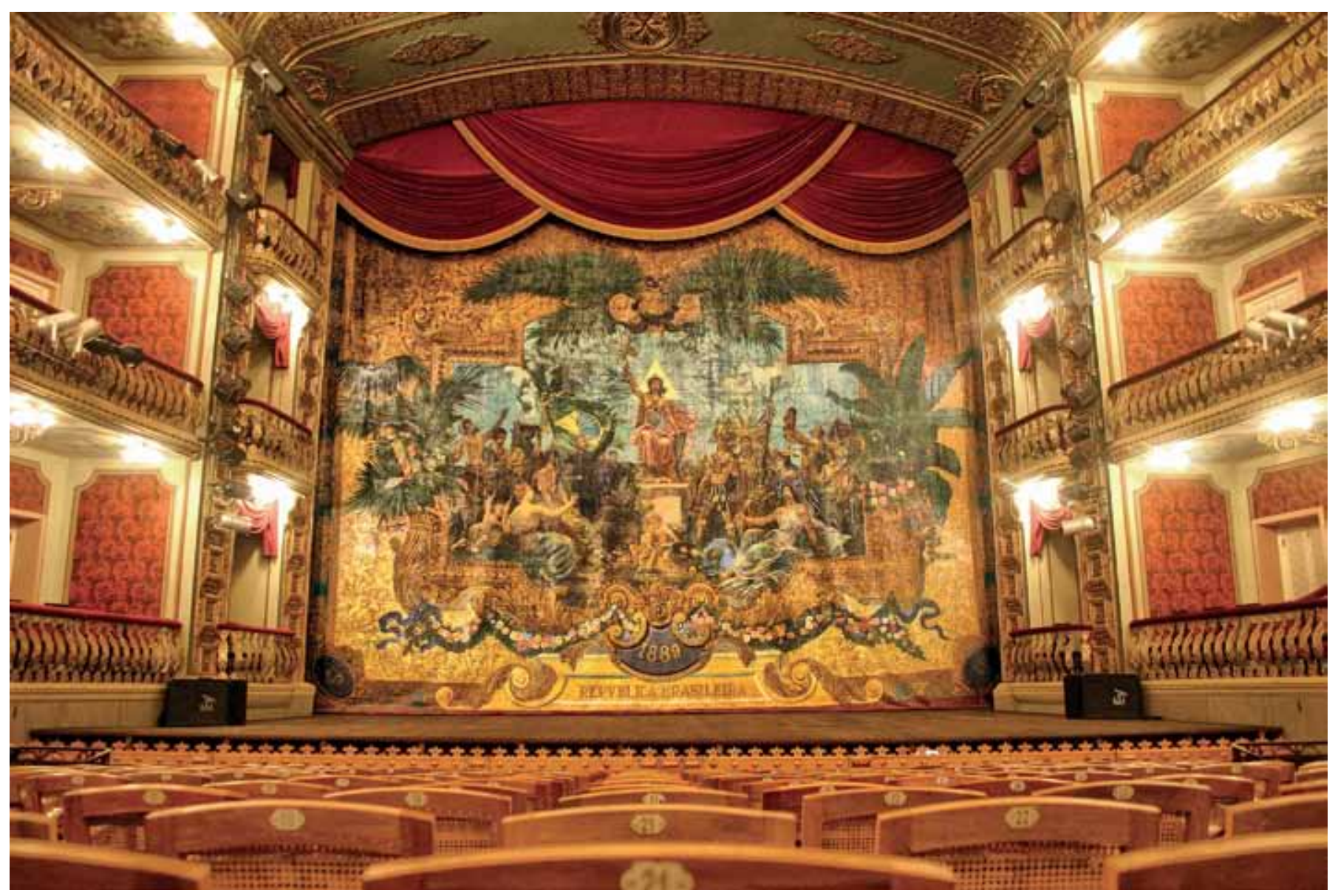

Figura 6 - Chrispim do Amaral, Pano de boca Alegoria da República. 1890. Óleo sobre tela. Teatro da Paz (Pará). Fotografia cedida pela autora. (C) Paula Sampaio. 


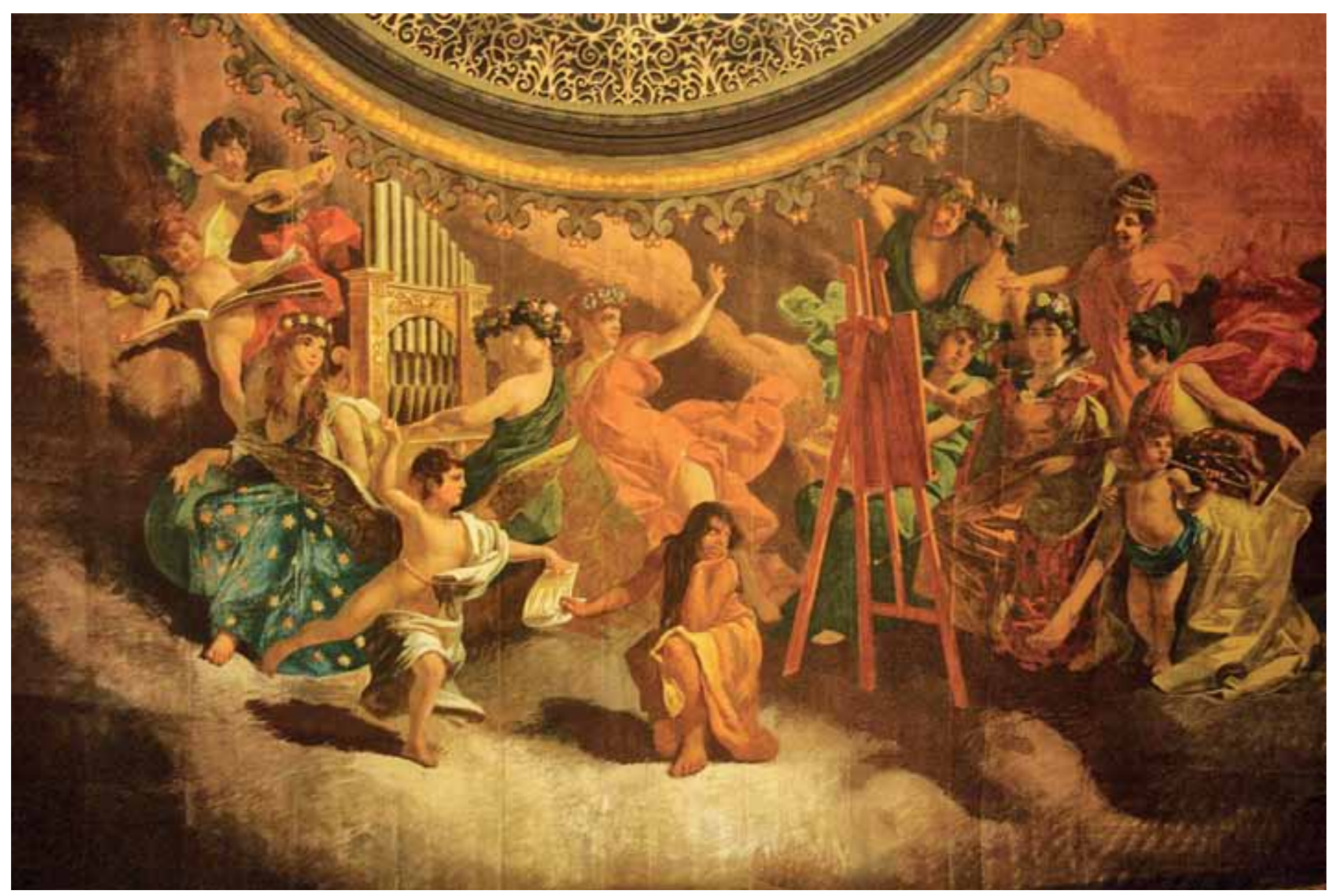

Figura 7 - Domenico de Angelis, a representação de Mnemosine e algumas das musas da arte, parte da pintura a têmpera do teto da sala de espetáculos. 1889. Teatro da Paz (Pará). Fotografia cedida pela autora. @ Paula Sampaio. 
empreendida por Augusto Montenegro, no início do século XX. E ainda hoje é comum atribuírem a alegoria do pano de boca ao cenógrafo francês Eugène Carpezat, em cujo atelier parisiense o trabalho foi realizado.

Nessa reforma, a orientação geral era concluir o embelezamento do prédio, alvo de tantas críticas desde sua inauguração. $\bigcirc$ Teatro da Paz não espelhava a sua função: ser um teatro de ópera. Nessa acepção, era preciso ter opulência, beleza e elegância. No Brasil, tais características poderiam sobrepujar até mesmo os aspectos técnicos. Em Belém, no dizer das autoridades, o teatro público deveria ser "o mais bello do Imperio". Veríssimo, na crônica da inauguração, foi implacável ao descrever o teatro e sua decoração pobre.

No meio d'aquelle luxo, d'aquelle explendor, só uma cousa era feia, o theatro. Se exteriormente o theatro da Paz é desgeitoso e em contrario a todas as regras da architectura, interiormente é nú, sem arte, sem gosto, sem riquezas, sem luxo.

Em um edificio que se quer dizer o primeiro do imperio, no seu genero, em que se gastou perto de 800 contos, o papel que forra os camarotes é o mais ordinario e feio possivel, os balcões dos camarotes são de madeira, as paredes são caiadas, as escadas nem envernisadas são e as cadeiras da platéa são n'omal [?]; o tecto é de lona pintada grotescamente com umas figuras de deuzas ou genios que parecem saloias, vermelhas, feias, horriveis, de grandes seios caidos, como velhas amas, capazes de fazer morrer de vergonha ou de riso, um artista que tivesse a coragem inaudita de olhal-as dous minutos.

A primeira reforma a fazer neste theatro é a do tecto. Por Deus! tire-se aquillo d'ali! Pintem-no antes todo de branco, mas não deixem a fazer-nos vergonha aquelle panno feio e aquellas figuras hediondas, mais proprias para uma barraca de feira de segunda ordem do que para um theatro qualquer. Levem aquillo para algum barracão de Nazareth.

A arcada do palco é nua como um Cupido. Não ha ali uma figura, um florão, qualquer cousa de ornato, nada, é de uma simplicidade pobre e sem gosto. $\bigcirc$ pano de bocca é simples; mas bonito. A entrada do theatro é desagradavel, é feia. E' baixa, chata, acachapada. N'aquelle vestibulo não ha uma fonte, uma estatua, nada. E' aquella brancura de cal e aquellas columnas de ferro, sem elegancia nenhuma, dando-lhe $o$ ar de um armazem de estação de estrada de ferro. Nada mais, nada menos. A unica qualidade boa deste theatro é ser fresco, como nunca vimos em theatro nenhum. Essa, pois, é grande.

Um architecto, enganei me, um mestre d'obras, acostumado a calcular, depois de um exame bem feito, o preço de um edificio, examinando o theatro da Paz dirá sem hesitar: - Não custou mais de 300 a 400 contos. Pois enganava-se redondamente, custou o dobro ${ }^{24}$.

Mas não era só o embelezamento a resolver. Quase dez anos depois de sua abertura, com funcionamento quase ininterrupto (pequenas obras foram feitas em 1883, obrigando a administração a um rápido fechamento), o teatro precisava de melhorias e atualizações. Faltava, entre muitos outros quesitos, retelhar todo o edifício por causa das inúmeras goteiras; consertar todo o madeiramento, podre em vários pontos do prédio, inclusive na área do arco do proscênio; canalizar água potável e esgoto; canalizar o gás para a iluminação; e decorar toda a sala de espetáculos, incluindo a confecção de cenários completos e de um pano de boca. 
Essa obra reeditou os imbróglios da fase construtiva quanto à gestão dos recursos financeiros e ao planejamento da obra. Falhas graves foram cometidas, como, por exemplo, a execução de serviços sem previsão orçamentária e sem contrato prévio, prejudicando o pagamento de fornecedores e prestadores de serviços, incluindo o pintor Domenico de Angelis, que esperou três anos para receber seus 12 contos de réis. Não por acaso houve contestação judicial de valores pagos pelo governo a um dos arrematantes da obra, na fase final.

A inserção das pinturas artísticas na sala de espetáculos, motivação primeira para a realização desta pesquisa, é uma síntese da burocracia e do jogo de poder na província do Pará às vésperas da passagem da Monarquia para a República. Chrispim do Amaral, pernambucano, cenógrafo, desenhista, jornalista, ator e músico, e Domenico de Angelis, renomado pintor formado na legendária Academia de San Luca, em Roma, conheciam os meandros desse jogo, mas não se tornaram invulneráveis a ele. No entanto, souberam fazer prevalecer sua criação artística: imagens que sobreviveram ao tempo e, dessa reforma, são as únicas remanescentes visíveis.

Os dois se conheceram em 1881, quando De Angelis aportou em Belém, acompanhado de Giovanni Capranesi, seu sócio, e do também pintor Sperindio Aliverti, contratados para a realização das pinturas decorativas da Catedral de Belém. Na capital paraense, De Angelis contratou artistas locais para compor a equipe e, entre eles, estava Chrispim do Amaral, cenógrafo conhecido na cidade por sua atuação na Empresa Vicente. A colaboração entre ambos ocorrev em outras oportunidades: em 1888, Amaral foi agraciado com uma bolsa de estudos do governo paraense, por intermédio de De Angelis, para aperfeiçoar-se em pintura na Academia de San Luca. Em 1893, foi contratado pelo governador Eduardo Ribeiro, do Amazonas, para executar a decoração, incluindo um pano de boca, do Teatro Amazonas, inaugurado em 31 de dezembro de 1896. Na oportunidade, recomendou De Angelis para a decoração do salão nobre do teatro de Manaus. Assim, por longos anos, Amaral e De Angelis dominaram as duas praças nortistas.

Em maio de 1887, o italiano assinou contrato com o governo, para realizar toda a decoração das dependências da sala de espetáculos - camarotes, plateia, paraísos, etc. -, assim como projetar e executar a pintura do teto. Para isso, ele contou com a colaboração dos artistas Silvio Centofanti, Adalberto de Andreis, Francesco Alegiani, José Gomes Corrêa de Faria e Chrispim do Amaral. O contrato do artista foi feito conjuntamente ao da firma Tavares \& Cia., ambos somando 70 contos de réis, que deveriam ser pagos até dezembro daquele ano. Com a falta de planejamento, as pinturas internas foram encerradas antes da realização de obras estruturais, não previstas, na cobertura e na área do proscênio. Resultado: De Angelis e sua equipe tiveram de retocar toda a decoração, sem o pintor jamais ser ressarcido dos custos adicionais desse trabalho.

Em seguida veio o episódio mais instigante da relação do italiano com o governo. Seu projeto de pintura do plafond já havia sido aprovado, mas um problema de interpretação do contrato, no tópico relacionado à técnica de pintura a ser utilizada, virou um assunto de Estado. O contrato referia-se a pintura a óleo, 
mas o artista defendia a pintura a têmpera, atrelando, de certo modo, a temática da obra à técnica. $\bigcirc$ administrador do teatro João Olympio Rangel, amparado no contrato, argumentava que a pintura a óleo seria de mais fácil manutenção, pois haveria artistas competentes para realizá-la, quando necessário, ao contrário da têmpera, para a qual não haveria técnicos capacitados na região.

Criou-se um impasse quanto a essa definição. Miguel José de Almeida Pernambuco, presidente da Província, recorreu ao pintor brasileiro Aurélio de Figueiredo (1854-1916), irmão mais novo de Pedro Américo. Sendo o seu parecer favorável à pintura a óleo, o presidente indeferiu a petição de De Angelis. Mas este não desistiv e, em janeiro de 1889, tendo feito uma explanação direta ao presidente, conseguiu dele a nomeação de uma comissão para apreciar a questão. A comissão foi formada por Constantino Pedro Chaves da Motta (1820-1899), paraense, pintor formado na Academia de San Luca; José Irineu de Souza (1 850-1924), cearense, formado no Liceu Imperial de Artes e Ofícios; e Heráclito Vespasiano Fiock Romano, deputado, representante da Assembleia Provincial.

grupo foi instado a responder quatro questões: se o teto do teatro estava apto a receber pintura a óleo ou a têmpera; qual o gênero de pintura mais apropriado ao teto de um teatro; se, em sendo o teto de madeira, deveria receber pintura a óleo ou a têmpera, segundo "os preceitos da arte"; e se não seria mais apropriado fazer uma pintura mais simples do que a proposta pelo artista. É interessante perceber, na última questão, um certo direcionamento do governo quanto à temática da pintura, item já aprovado e que, por isso, deveria estar fora de discussão. Se a ideia era embelezar o teatro, é de se supor que uma pintura mais elaborada fosse o ideal naquele momento. Diante disso, não há como deixar de mencionar a instituição da censura, no Império, como um dispositivo para a manutenção da ordem. A criação, em 1841, do Conservatório Dramático Brasileiro, na Corte, atendeu a essa orientação quanto às artes, estendendo às instituições congêneres nas províncias as mesmas prerrogativas. Mas, em Belém, - Conservatório Dramático Paraense, por motivos desconhecidos, não se envolveu nessa questão.

A comissão votou pela pintura a óleo, desde que fossem corrigidos os defeitos do teto de madeira, e pela inteira liberdade de criação do artista. $\bigcirc$ parecer produzido por essa comissão traz, entre outras qualidades, um indicativo da concepção de arte e estética do momento, impregnada pela definição do alemão Alexander Gottlieb Baumgarten (1714-1762): a estética é a ciência do belo, sendo esta aferida no momento da contemplação da obra de arte. Um trecho desse documento é fundamental para essa percepção:

Sendo a esthetica a sciencia do bello, esta qualidade se nos manifesta em qualquer paragem onde ella esteja efectivamente.

Em diversos materiaes se tem pintado e ou o que se pintou continha o preceito da esthetica e era realmente bello, ou não estava em tal caso.

É inquestionável que para analysar qualquer trabalho nas duas circunstancias ditas não devemos indagar em que foram elles feitos, mas tão somente se em sua execução se observaram os preceitos dessa sciencia.

Annals of Museu Paulista. v. 18. n.2. July.-Dec. 2010. 
25. Cf. Parecer da comissão (1889). $\bigcirc$ verdadeiro e o bello gosam sempre de suas qualidades, assim é que um pintor de merecimento que executasse um retrato da Augusta Mãe do Divino Mestre o poderia ter creado com verdade, bellesa e perfeição, quer fizesse o trabalho sobre tela, madeira, ou simplesmente sobre barro.

Voltando ainda a occupar-nos das questões propostas, devemos francamente declarar a $\mathrm{V}$. Exa. que devendo ter cada edifício suas regras, ou segundo a sua riqueza architectonica, ou em relação ao meio ou região em que esteja situado, não se pode afirmar com vantagem se deve ser simples ou trabalhosamente decorado o tecto de um theatro.

Certos de quem em obediências as leis do bom gosto parece-nos que não prejudica de forma alguma aos fins para que se destina um theatro o ser o seo tecto decorado luxuosamente, desde que haja por parte do artista encarregado de tal trabalho a inspiração no verdadeiramente Bello e sciencia na escolha de assumpto para sua geral execução ${ }^{25}$.

Mas, nessa queda de braço, prevaleceu a vontade de De Angelis. Uma mudança na presidência e outra na administração do teatro o favoreceram, pois ele realmente pintou o teto a têmpera e o entregou pronto no final daquele mesmo ano, já no governo republicano. Em 1896, o pintor voltaria a ser contratado pelo governo para decorar o salão nobre do teatro, como forma de compensação pelos prejuízos sofridos. De todas, é a única pintura não mais existente no teatro, pois foi destruída pelas infiltrações no teto do salão nobre. $\mathrm{Na}$ década de 1960, foram substituídas pelas pinturas do também italiano Armando Balloni.

A obra de De Angelis no plafond é uma reunião de personagens mitológicos, a começar pelo deus Apolo, em uma versão multifacetada, com atributos greco-romanos e celtas. Ele abre caminho para as musas, representadas em três nichos da pintura elíptica. Essas figuras são entremeadas por representações indígenas e tapuias, sinalizando a natureza e a cultura da região amazônica, embora claramente o conjunto pictórico reitere a supremacia europeia sobre aquele mundo novo, desconhecido e exótico.

Nessa reforma, o percurso de Chrispim do Amaral é sobretudo curioso. Em 1886, o artista pernambucano apresentou uma proposta orçamentária para confeccionar um pano de boca (incluindo o maquinismo) por três contos de réis. Amaral fez um estudo de um pano de boca em tom de vermelho vivo, com uma barra floral, entremeada por douramentos, e o encaminhou junto ao memorial. Esse estudo desapareceu dos documentos do Arquivo Público do Estado do Pará, mas, na fase inicial da sua investigação, ainda foi visto por esta pesquisadora.

Amaral era tido como o único artista cenógrafo da cidade. No entanto, o seu nome e seu orçamento pareciam não agradar às autoridades de então. Discussões de bastidores, documentadas em ofícios e despachos, dão conta disso. A tendência era mandar fazer o serviço na Europa ou na Corte, onde, acreditavam as autoridades, haveria melhor preço e melhor qualidade no serviço. Dessa resistência, pode deduzir-se uma saturação quanto ao trabalho do artista, já transformado em "o artista" da província, depois de tantos anos radicado no Pará. Ele mesmo lutara para sair de Belém e ir estudar na Europa, tendo conquistado, em 1888, a já citada bolsa de estudos. 
assunto prosseguiu por longos anos. Em 1889, uma nova proposta de Amaral, a esta altura estudando em Roma, circulava na administração da Província suscitando debates. $\bigcirc$ administrador do teatro, José Caetano da Gama e Silva, ao mesmo tempo em que apresentava a proposta do artista, de 23 contos de réis, desqualificava-a.

Logo que a Assemblea marque a respectiva verba pedirei a $V$. Exa. permissão para entender-me com o nosso Consulo-Geral em Genova, que é um paraense muito distincto, afim de serem contractados os artistas scenographos para pintarem todo o scenario e panno de bocca do Theatro, pois julgo que por esta forma se poderá conseguir mais perfeito e por menor preço que o que consta do orçamento por mim encontrado e feito pelo artista C. do Amaral26.

A autorização para a contratação do artista ocorreu pouco antes do advento da República. As fontes indicam que a decisão pode ter partido do presidente Antônio José Ferreira Braga, pois, em 1ำ de outubro de 1889, ele assinou documentos relevantes, incluindo a homologação do Regulamento das Obras Públicas, reorganizando o setor. Mas é mais provável que tenha sido encaminhada pelo último presidente da Província, Silvino Cavalcante de Albuquerque, embora ele tenha permanecido apenas dois dias no cargo, de 14 a 16 de novembro, sendo deposto por um grupo de republicanos. Coincidentemente, no dia da chegada de Albuquerque a Belém, uma nota no jornal $\bigcirc$ Liberal do Pará defendia a contratação de Amaral e o seu orçamento. Mas foi a Junta Provisória do Estado do Pará, estabelecida após a deposição de Albuquerque, a responsável pela efetivação do contrato, conforme os ofícios do administrador Gama e Silva, mantido no cargo.

A scenographia do theatro, que se comprará das peças constantes do Annexo nº 2, foi contractado pelo antecessor de V.V.E.Ex ${ }^{\text {as }}$ com o artista Chrispim do Amaral pela quantia de 23 contos de reis; e como este contracto não chegou a ser assignado no Thesouro Publico do Estado, consulto se ainda tem vigor aquelle acto do ex-presidente e se o Thezouro pode ultimar o dito contracto ${ }^{27}$.

Em nova comunicação com o governo, demonstrava ter sido encerrado o assunto sobre o contrato com o pintor.

Illmos. Exmos. Sen ${ }^{\text {rs }}$.

Confirmando o meo officio de 26 de novembro ppdo, em que consultei se estava em vigor o contracto feito com Crispim do Amaral para a scenographia do Theatro, afim de, no cazo contrario, sem perda de tempo, poder esta administração tratar de annunciar nova arrematação perante o Thesouro do Estado, vem esta administração tratar agora de outras obras, também urgentes ${ }^{28}$.

Essa documentação esclarece a dúvida sobre a autoria do pano de boca do teatro da Paz, apesar de sua assinatura não aparecer na peça, onde consta a marca do Atelier Carpezat. Durante sua estada na Europa, Amaral conheceu Carpezat, cenógrafo da Ópera de Paris. Trabalharia com ele novamente
26. Cf. Ofício do administrador (1889a); grifos nossos.

27. Cf. Ofício do administrador (1889b).

28. Cf. Ofício do administrador $(1889 \mathrm{c})$.

Annals of Museu Paulista. v. 18. n.2. July.-Dec. 2010. 
29. Cf. Vicente Salles (1994, p. 135). Salles também fez essa afirmação diretamente à autora deste artigo.

30. Cf. José Murilo de Carvalho (1990, p. 80). em 1891, quando o governo do Pará encomendou outra cenografia ao artista, substituindo a que havia sido estragada pelas infiltrações. Em suas propostas, Amaral é claro ao mencionar o trabalho de técnicos da Nova Ópera de Paris. Corrobora essa ideia o historiador Vicente Salles ${ }^{29}$, seguindo a argumentação do historiador baiano Clarival do Prado Valladares, que via nos motivos temáticos da pintura uma aproximação com a estética do pernambucano.

A alegoria do pano de boca reúne a figura de Marianne, uma síntese das representações de 1789 e 1848, ladeada por personagens da mitologia greco-romana, de elementos indígenas e caboclos, em meio a oficiais participantes do movimento republicano. Estudioso das representações republicanas, o historiador José Murilo de Carvalho ressalta que o baiano Manuel Lopes Rodrigues, autor de uma Alegoria da República, de 1896, só poderia tê-la concebido com os atributos da Segunda República porque vivia na Europa, onde esses elementos já haviam sido apropriados ${ }^{30}$. Para ele, talvez não haja outra pintura de igual valor. É lícito incluir Amaral nessa lista, pois sua pintura, além da qualidade estética, é a primeira representação republicana concebida no Pará e, provavelmente, no Brasil, além de integrar-se a um teatro-monumento.

O resultado da reforma foi conferido pelo público em julho de 1890, quando o teatro foi reinaugurado. A obra demorou o suficiente para haver troca do sistema de iluminação, de gás para energia elétrica, embora este fornecimento só tenha sido aperfeiçoado na década de 1890. Em 22 de julho, subiu à cena a Companhia Lírica Italiana, empresariada pelo maestro paraense José Cândido da Gama Malcher, encenando a ópera A Sonâmbula, de Vicenzo Bellini.

A inauguração do pano de boca só ocorreu na récita, de 15 de agosto, da ópera Ernani, de Giuseppe Verdi, causando impacto. Os relatos da época mencionam a vaia da plateia quando da apresentação oficial do pano, pois a figura de um mulato carregando a bandeira nacional teria sido um choque, impondo "revolta ao civismo nacional", segundo o administrador Victor Maria da Silva.

As pinturas de Domenico de Angelis e Chrispim do Amaral são hoje dois ícones do Teatro da Paz e já não suscitam polêmicas. Para elas incide o olhar contemplativo de quem adentra a sala de espetáculos. Integradas à edificação, merecem mais estudos, para serem reativadas na sua capacidade discursiva e reiteradas como obras de arte. Dessa forma, ao renovar-the o sentido, o público concorre para tomá-las como patrimônio, que de fato são, evitando a reedição de períodos de abandono no século XX, quando houve a perda total da pintura de De Angelis no salão nobre; ou, na década de 1960, quando o telão de Amaral foi visto no palco do teatro, servindo de pano de chão, quase indo parar na lata de lixo.

A reiteração do sentido de patrimônio, muito além da existência necessária e desejada de uma legislação específica de proteção, está associada à experiência da sociedade diante de seus monumentos. $\bigcirc$ Teatro da Paz, mais do que um fetiche, é um monumento, um artefato, um produto de mãos e sentimentos humanos. 


\section{REFERÊNCIAS}

\section{FONTES}

Arquivos e acervos

ARQUIVO PÚBLICO DO ESTADO (Belém, Pará):

ATA do Lançamento da Pedra Fundamental do Theatro da Paz. Belém, 8 de março de 1869. Códice n. 1.426 (antigo 1.014).

PARECER da comissão, Belém, Pará, 9 de janeiro de 1889. In: SECRETARIA DO GOVERNO. Ofícios da Administração do Theatro N. S. da Paz (1889-1899).

OFÍCIO encaminhado pelo administrador do Teatro da Paz, João Olympio Rangel, ao presidente da província, conselheiro João Antônio de Araújo Freitas Henriques. Belém, Pará, 30 jul. 1886. In: SECRETARIA DA PRESIDÊNCIA DA PROVÍNCIA. Ofícios da Administração do Theatro da Paz (1882-1888). Série $13^{\mathrm{a}}$ (Ofícios). Anexo.

OFÍCIO do administrador do Theatro da Paz, José Caetano da Gama e Silva, ao presidente da Província, Antônio José Ferreira Braga, Belém, Pará, 24 ago 1889a. In: SECRETARIA DA PRESIDÊNCIA DA PROVÍNCIA. Ofícios da Administração do Theatro N. S. da Paz (1889-1899). Contém anexos.

OFÍCIO do administrador do Theatro da Paz, José Caetano da Gama e Silva, ao presidente e mais membros do Governo Provisório do Estado Federal do Pará, Belém, Pará, 27 nov. 1889b. In: SECRETARIA DA PRESIDÊNCIA DA PROVÍNCIA. Ofícios da Administração do Theatro N. S. da Paz (1889-1899). Contém anexos.

OFÍCIO do administrador do Theatro da Paz, José Caetano da Gama e Silva, aos membros do Governo Provisório do Estado do Pará. Belém, Pará, 12 dez. 1889c. In: SECRETARIA DA PRESIDÊNCIA DA PROVÍNCIA. Ofícios da Administração do Theatro N. S. da Paz (1889-1899).

\section{CENTER FOR RESEARCH LIBRARIES (CHICAGO):}

RELATORIO apresentado á Assembléa Legislativa Provincial do Pará no dia 15 de agosto de 1856, por occasião da abertura da primeira sessão da 10.a legislatura da mesma Assembléa, pelo presidente, Henrique de Beaurepaire Rohan. [n.p.] Typ. de Santos \& filhos, 1856. p. 15-16.

RELATORIO lido pelo exmo. sr. vice-presidente da provincia, dr. Ambrosio Leitão da Cunha, na abertura da primeira sessão ordinaria da XI legislatura da Assemblea Legislativa Provincial no dia 15 de agosto de 1858. Pará: Typ. Commercial de Antonio José Rabello Guimarães, 1858.

Discursos e falas de autoridades do Pará nos anos de 1830, 1840, 1850, 1860, 1870, 1880, 1890, 1905 e 1908.

\section{MUSEU DA UNIVERSIDADE FEDERAL DO PARÁ (SALA VICENTE SALLES):}

A EXPOSIÇÃO artística e industrial do Lyceu Benjamin Constant e os expositores em 1895. Com litografias de C. Wiengandt Belém: Typ. do Diario Official, 1895.

BELÉM (Pará). Intendência Municipal. Álbum de Belém: Pará 15 de novembro de 1902. Belém: Edição Felipe Augusto Fidanza, 1902. 


\section{Imagens}

ALBUM DESCRITTIVO do Pará. Gênova: Fototip. Stab. Armanino, 1898.

AMARAL, Chrispim do. Alegoria da República. 1890. 1 original de arte, óleo sobre tela, 105m² Acervo do Teatro da Paz. Telão da sala de espetáculos.

DE ANGELIS, Domenico. Alegoria. 1889. 1 original de arte, têmpera sobre tela, color, $245 \mathrm{~m}^{2}$. Acervo do Teatro da Paz. Plafond da sala de espetáculos.

GRONSFELD, Gaspar. Planta Geral da Cidade do Pará, ca. 1771. Belém: Alunorte, 1995. Documento original (color) pertencente ao acervo do IHGB, RJ.

PARÁ. Governo do Estado, 1899 (José Paes de Carvalho). Álbum do Pará em 1899: na administração de sua excia. o sr. dr. José Paes de Carvalho. Belém: Felipe Augusto Fidanza, 1899.

PARÁ. Governo do Estado, 1901-1909 (Augusto Montenegro). Álbum do Estado do Pará: oito annos de governo. Paris: Chaponet, 1908.

Jornais

THEATRO de N. S. da Paz. O Liberal do Pará, Belém, n. 148, p. 1, 3 jul. $1875 a$.

THEATRO de N. S. da Paz. O Liberal do Pará, Belém, n. 151, p. 2, 7 jul. $1875 b$.

VERÍSSIMO, José. Chronica theatral. O Liberal do Pará, Belém, n. 40, 17 fev. 1878a. Folhetim, p. 1. Chronica theatral. O Liberal do Pará, Belém, n. 152, 7 jul. 1878b. Folhetim, p. 1. . Chronica theatral. O Liberal do Pará, Belém, n. 199, 1o set. 1878c. Folhetim, p. 2.

Sonora

BAHIA, Xisto. Camaleão. Rio de Janeiro: Odeon, 1902. (1min25). Intérprete: Maria Martha. In: Conexão Política: site oficial de Franklin Martins. Disponível em: <http://www.franklinmartins. com.br/som_na_caixa_gravacao.php?titulo=camaleao\#>. Acesso em: 23 jan. 2009.

LIVROS, ARTIGOS E DISSERTAÇÕES

ALMANAK LAEMMERT. Almanak Administrativo Mercantil e Industrial do Império do Brazil para 1883, Rio de Janeiro, anno 40, v. 1. Disponível em: http://brazil.crl.edu/bsd/bsd/almanak/ al1883/.

CARVALHO, José Murilo de. A formação das almas: o imaginário da República no Brasil. 16. reimp. São Paulo: Companhia das Letras, 1990.

CERTEAU, Michel de. A invenção do cotidiano, 1: artes de fazer. Trad. Ephraim Ferreira Alves. Rio de Janeiro: Vozes, 1994.

JURANDIR, Dalcídio. Chove nos campos de Cachoeira. Belém: Cejup; Secult, 1997.

MATTOSO, Ernesto. O dr. Augusto Montenegro: sua vida e seu governo. Paris: Tony Dussieux, 1907.

MITRE, Antonio. O dilema do centauro: ensaios de teoria da história e pensamento latino-americano. Belo Horizonte: UFMG, 2002.

SALLES, Vicente. A música e o tempo no Grão-Pará, 1. Belém: Conselho Estadual de Cultura, 1980.

Crispim do Amaral. In: ARAÚJO, Emanoel (org.). A mão afro-brasileira: significado da contribuição artística e histórica. São Paulo: Tenenge, 1988. p. 163-166. . Épocas do teatro no Grão-Pará ou apresentação do teatro de época. Belém: UFPA, 1994. t. 1 e 2 .

. Marxismo, socialismo e os militantes excluídos: capítulos da história do Pará. Belém: Paka-Tatu, 2001a.

Traços E troças: o desenho de crítica e de humor no Pará. Brasília: MicroEdição do Autor, $2001 b$. v. 1. Trabalho inédito. Música e músicos do Pará. Belém: Secretaria de Estado da Cultura do Pará, 2007. 
SOUZA, Roseane Silveira de. Histórias invisíveis do Teatro da Paz: da construção à primeira reforma - Belém do Grão-Pará (1869-1890), . 2009. Dissertação (Mestrado em História) - Programa de Estudos Pós-graduados em História, Pontifícia Universidade Católica de São Paulo (PUC-SP), São Paulo, 2009.

SÍTIOS

BIBLIOTECA VIRTUAL DO AMAZONAS. Manaus: Governo do Amazonas, 2001-2004. Disponível em: http://www.bv.am.gov.br/portal/. Acesso em: 4 fev. 2008.

CENTER FOR RESEARCH LIBRARIES. Brazilian Government Document Digitalization Project (Provincial Presidential Reports, Pará). Chicago. Disponível em: <http://www.crl.edu/content/ brazil/para.htm>. Acesso em: 2010.

CONEXÃO POLÍTICA (sítio oficial de Franklin Martins). Disponível em: <http://www. franklinmartins.com.br/som_na_caixa_gravacao.php?titulo=camaleao\#>. Acesso em: 23 jan. 2009.

TEATRO DA PAZ (página oficial). Disponível em <http//:www.theatrodapaz.com.br $>$. Acesso em: 2010. 